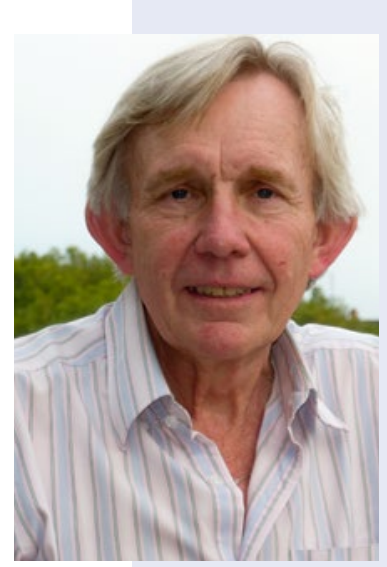

Wim Otto

\title{
Afscheid van het oude normaal
}

\section{Wim Otto}

Het afgelopen jaar hebben we voorlopig afscheid moeten nemen van wat we het oude normaal zijn gaan noemen. Onderdelen van de economie staan nog steeds vrijwel stil en een flink deel van de beroepsbevolking is anders gaan werken - van huis uit als het even kan, overigens vele malen te verkiezen boven verlies van werk. Sommigen bejubelen welhaast deze nieuwe situatie, benadrukken dat de coronacrisis nieuwe kansen biedt en toch al gewenste ontwikkelingen in een stroomversnelling brengt. De laatste maanden hoor ik toch ook steeds vaker dat mensen het zat worden, vooral vanwege de beperkingen in het sociale verkeer en de negatieve invloed die dat heeft, zowel op hun welzijn als op hun werk. Voor sociaalgeneeskundigen, die het functioneren van mensen vanuit een biopsychosociaal perspectief moeten beoordelen, bepaald geen verrassing, zou ik denken.

Maar voorlopig blijft corona nog even de baas en krijgen bedrijfs- en verzekeringsartsen steeds meer te maken met de gevolgen van een doorgemaakte COVID-19 op het kunnen functioneren in werk. Niet alleen met gevolgen op de korte termijn, maar zeker ook op de langere termijn, zoals intussen steeds duidelijker wordt. Daarom is de winterspecial in deze editie aan COVID-19 gewijd. De aanvankelijke insteek om ons te beperken tot de langetermijngevolgen van COVID-19 heeft de redactie al snel losgelaten, omdat er meer te melden valt en we interessante informatie niet willen laten 'verpieteren'. We willen juist zo actueel mogelijke informatie bieden die erop is gericht om kennis en praktijkervaring te delen die voor bedrijfs- en verzekeringsartsen iets toevoegt aan de grote hoeveelheid informatie die er al wordt geboden op virologisch, klinisch en epidemiologisch gebied. Zeker op ons vakgebied zal die kennis en ervaring de komende tijd in snel tempo verder worden ontwikkeld en in die zin zien wij deze special graag als een aftrap voor meer publicaties. Voor TBV-3 staat al een en ander in de planning, daarnaast nodigen wij ook $\mathrm{u}$ uitdrukkelijk uit om vanuit uw eigen praktijk voor vakgenoten bruikbare ervaringen te delen.

Hoe actueel kun je zijn met een onderwerp als COVID-19? En dan vooral: hoe actueel kun je zijn bij een papieren uitgave als de kopij bijna twee maanden voor verschijningsdatum al helemaal klaar moet zijn? En als het aanbod wisselend is en je soms artikelen niet in de eerstvolgende editie kunt plaatsen? Dat wringt natuurlijk regelmatig, zeker als je vindt dat je het als vaktijdschrift aan je stand verplicht bent om liefst bovenop bepaalde ontwikkelingen te zitten. COVID-19 maakt dat extra duidelijk, maar al voor de crisis werd door de SBBV ${ }^{1}$ onderkend dat TBV aan vernieuwing toe is. Daarom is in 2020 een plan ontwikkeld om die vernieuwing vorm te geven. Een belangrijk onderdeel daarvan is dat we een digitaal platform willen ontwikkelen, dat naast meer actualiteit ook meer dynamiek moet bieden: meer opinie en discussies door een laagdrempelige en snelle publicatiemogelijkheid. Het tijdschrift verdwijnt niet, papier en digitaal moeten elkaar aanvullen en zo tezamen tot een veel completer vak'blad' leiden.

De praktische voorbereidingen zullen in de eerste helft van dit jaar plaatsvinden. Tot de zomer verandert er dus nog even niets, maar daarna zal het huidige TBV-concept tot het oude normaal gaan behoren. Dat afscheid is definitief, net zoals veel van het oude normaal uit het precoronatijdperk niet meer terug zal komen.

Moge 2021 een jaar worden waarin we kunnen bouwen en vernieuwen, niet in de laatste plaats aan TBV. Ik wens u namens de redactie een goed jaar met veel nieuw perspectief.

1. Stichting tot Bevordering der Bedrijfs- en Verzekeringsgeneeskunde, de opdrachtgever voor de uitgave van TBV. In het stichtingsbestuur hebben vertegenwoordigers van NVAB en NVVG zitting. 